\title{
Life cycle of the nematode Contracaecum rudolphii Hartwig, 1964 (sensu lato) from northern Poland under laboratory conditions
}

\author{
J. DZIEKOŃSKA-RYNKO ${ }^{1}$, J. ROKICKI ${ }^{2}$
}

${ }^{1}$ Faculty of Biology, Chair of Zoology, University of Warmia and Mazury, 10-957 Olsztyn, ul. Oczapowskiego 5, E-mail: jdr@uwm.edu.pl; ${ }^{2}$ Department of Invertebrate Zoology, University of Gdańsk, Gdynia, Al. Piłsudskiego 46

\begin{abstract}
Summary
The study was aimed at following, under laboratory conditions, embryogenesis of the nematode Contracaecum rudolphii, and at identifying its intermediate hosts in northeastern Poland. Nematode eggs, isolated from the terminal part of the female uterus, were placed in 0.9 and $3 \% \mathrm{NaCl}$ solutions, $1 \%$ formalin, and in tap water. Each solution batch was divided into 3 parts kept at 4,15 , and $23^{\circ} \mathrm{C}$. Regardless of the temperature they were exposed to, the eggs placed in $1 \%$ formalin showed numerous deformations; as few as $5 \%$ of those eggs produced larvae. Embryogenesis was at its fastest in the eggs kept at $23^{\circ} \mathrm{C}$. While still within the eggs, the larvae underwent two moults. The eggs hatched to produce the stage 3 larvae, which emerged surrounded by the cuticle of the preceding larval stage. Experimental infestations of zooplankton collected from Lake Kortowskie showed that only cyclopoid copepods could serve as the intermediate hosts. No differences in the infestation intensity were found between the guppies infested by the invasive larvae and those fed the infested cyclopoids.
\end{abstract}

Key words: Contracaecum rudolphii; parasitic Nematoda; cormorant; embryogenesis; life cycle

\section{Introduction}

Contracaecum rudolphii is a cosmopolitan parasite of piscivorous birds (Huizinga, 1971; Nottenkämper et al., 1999; Kuiken et al., 1999; Torres et al., 2000; Abollo et al., 2001; Kanarek et al., 2002; Torres et al., 2005; Sanmartin et al., 2005). In Europe, the nematode finds its definitive hosts mainly in cormorants (Phalacrocorax carbo, Ph. Aristotelis) and sea ducks (Mergus merganser and M. serrator) (Moravec, 1994).

Thomas $(1937 \mathrm{a}, \mathrm{b})$ was the first to study the life cycle of Contracaecum rudolphii (reported as C. spiculigerum) found in piscivorous birds in the United States. He found the parasite's life cycle to be simple: the eggs developed in water for about 5 days and gave rise to invasive, free-living larvae. When fed to guppies, the larvae penetrated the fish intestines and moved to the peritoneal membrane and other internal organs to encyst. Olsen (1962) found the life cycle of $C$. spiculigerum in piscivorous birds in the US to involve copepods as intermediate hosts. Huizinga (1966) reportted the life cycle of the parasite in the US to be complex, the role of paratenic hosts being played by freshwater or marine copepods. The larvae grew in the copepod body, but did not moult there. The role of intermediate hosts was played by the fish which may become infested by freeliving larvae or by ingesting infested copepods. When in the fish body, the larvae migrated from the intestine to the body cavity to encapsulate there. In 1963 - 1966, Mosgovoy et al. (1968) studied the life cycle of C. rudolphii in Krasnodarskiy Kray and in Azerbaijan. They tried to induce experimental infestations in numerous invertebrates (crustaceans, oligochaetes, molluscs), but succeeded only with copepods and dragon-fly larvae. Mosgovoy et al. (1968) concluded that copepods were paratenic hosts, while larvae of dragon-flies of the genera Coenagrion and $\mathrm{Ag}$ rion served as intermediate hosts. Mosgovoy et al. (1968) found the infestation intensity and prevalence in dragon-fly larvae to be very high, particularly if they had been earlier fed infested cyclopoids. According to Mosgovoy et al. (1968), C. rudolphii larvae, when in the dragon-fly body, develop much faster than in the fish body, although the fish which, too, may be intermediate hosts. Mosgovoy et al. (1968) succeeded in inducing experimental infestation in cormorants only after feeding them larvae isolated from the dragon-fly larvae infested earlier. No infestation occurred when the cormorants were fed infested cyclopoids or larvae isolated from the experimentally infested fish. In her study on morphogenesis of larval C. rudolphii from experimentally infested copepods, amphipods (Gammarus sp.), and fish, Bartlett (1996) found copepods and amphipods to 
be paratenic hosts, while only the fish served as the parasite's intermediate hosts.

The available literature lacks data on the life cycle and intermediate hosts of the parasite in Poland. Infestation prevalence in cormorants in northern Poland may be as high as almost $100 \%$ (Kanarek et al., 2002). In their study on the cormorant colony at Katy Rybackie, Martyniak et al. $(1997,2003)$ found the cormorant diet to be dominated by ruffe, smelt, herring, perch, and roach. Most probably, the cormorant forage in the Vistula Lagoon and the Baltic Sea. When examining different fish species from the Vistula Lagoon in 1994 - 1997, Rolbiecki (2003) failed to find $C$. rudolphii larvae. Similarly, Dzika (2003) did not find the parasite in the fish of Lake Wulpińskie which supports a cormorant colony as well.

This study was aimed at following the parasite's embryonic development under laboratory conditions and at identifying its intermediate hosts in north-eastern Poland.

\section{Materials and Methods}

\section{Embryonic development}

Adult nematodes were isolated from the digestive tracts of cormorants dwelling in a colony at Kąty Rybackie. Nematode eggs were removed, using a needle, from the terminal section of adult female uterus and placed in $0.9 \% \mathrm{NaCl}$, $3 \% \mathrm{NaCl}, 1 \%$ formalin, and tap water. Each solution batch was divided into three parts, each to be incubated at 4, 15, and $23^{\circ} \mathrm{C}$ (Table 1). The advancement of egg development in all the solutions was checked daily by examining the eggs under a Biolar compound microscope at $20 \times 12.5$ magnification. Some of the eggs were placed for 2 months at $-17^{\circ} \mathrm{C}$, following which they were transferred to $23^{\circ} \mathrm{C}$ and handled as described above.

Zooplankton and fish were infested with the larvae incubated in $0.9 \% \mathrm{NaCl}$.

Measurements and photographs were taken under an

Table 1. The development of C. rudolphii eggs in different media and at different temperatures

\begin{tabular}{|c|c|c|c|c|c|c|c|c|c|}
\hline \multirow{3}{*}{ Day } & \multirow{3}{*}{$\begin{array}{l}\text { The stage of } \\
\text { development }\end{array}$} & \multicolumn{8}{|c|}{ Mean $\%$ and standard deviation } \\
\hline & & \multicolumn{4}{|c|}{$15^{\circ} \mathrm{C}$} & \multicolumn{4}{|c|}{$23^{\circ} \mathrm{C}$} \\
\hline & & $\begin{array}{c}\text { Tap } \\
\text { water }\end{array}$ & $\begin{array}{l}0.9 \% \\
\mathrm{NaCl} \\
\end{array}$ & $\begin{array}{l}3 \% \\
\mathrm{NaCl} \\
\end{array}$ & $\begin{array}{c}1 \% \\
\text { Formalin } \\
\end{array}$ & $\begin{array}{c}\text { Tap } \\
\text { water }\end{array}$ & $\begin{array}{l}0.9 \% \\
\mathrm{NaCl} \\
\end{array}$ & $\begin{array}{l}3 \% \\
\mathrm{NaCl} \\
\end{array}$ & $\begin{array}{c}1 \% \\
\text { Formalin } \\
\end{array}$ \\
\hline 2 & I & $5 \pm 1.8$ & $8 \pm 2.5$ & $4 \pm 1.5$ & $5 \pm 3.2$ & $75 \pm 4.6$ & $87 \pm 9.7$ & $82 \pm 4.6$ & $65 \pm 4.6$ \\
\hline \multirow[t]{2}{*}{3} & I & $10 \pm 3.5$ & $15 \pm 3.5$ & $13 \pm 3.6$ & $10 \pm 3.5$ & $20 \pm 3.5$ & $12 \pm 2.4$ & $13 \pm 3.5$ & $25 \pm 1.8$ \\
\hline & II & & & & & $67 \pm 2.5$ & $73 \pm 9.8$ & $74 \pm 3.8$ & $37 \pm 2.8$ \\
\hline \multirow[t]{3}{*}{4} & I & $18 \pm 2.6$ & $22 \pm 2.8$ & $15 \pm 1.5$ & $16 \pm 2.6$ & $13 \pm 3.6$ & $12 \pm 2.6$ & $8 \pm 1.6$ & $10 \pm 1.8$ \\
\hline & II & $8 \pm 4.5$ & $5 \pm 1.5$ & $2 \pm 0.5$ & $3 \pm 1.7$ & $10 \pm 4.5$ & $8 \pm 1.7$ & $12 \pm 4.5$ & $53 \pm 2.5$ \\
\hline & III & & & & & $67 \pm 5.5$ & $72 \pm 8.1$ & $69 \pm 3.8$ & \\
\hline \multirow[t]{4}{*}{5} & I & $39 \pm 1.6$ & $46 \pm 2.8$ & $18 \pm 1.7$ & $18 \pm 1.8$ & 0.0 & 0.0 & $4 \pm 2.3$ & $5 \pm 3.7$ \\
\hline & II & $9 \pm 5.8$ & $10 \pm 4.8$ & $7 \pm 3.5$ & $5 \pm 1.8$ & $5 \pm 3.3$ & $5 \pm 2.5$ & $9 \pm 0.3$ & $58 \pm 3.3$ \\
\hline & III & & & & & $10 \pm 4.7$ & $9 \pm 3.6$ & $12 \pm 2.7$ & $5 \pm 2.7$ \\
\hline & IV & & & & & $79 \pm 5.6$ & $77 \pm 6.6$ & $60 \pm 3.7$ & \\
\hline \multirow[t]{2}{*}{6} & I & $76 \pm 3.3$ & $73 \pm 2.3$ & $63 \pm 2.5$ & $60 \pm 3.3$ & & & & \\
\hline & II & $14 \pm 3.3$ & $15 \pm 1.4$ & $12 \pm 1.7$ & $10 \pm 1.3$ & & & & \\
\hline \multirow[t]{2}{*}{7} & I & $53 \pm 3.5$ & $50 \pm 3.8$ & $57 \pm 4.5$ & $56 \pm 3.8$ & & & & \\
\hline & II & $38 \pm 1.4$ & $40 \pm 2.3$ & $28 \pm 1.2$ & $21 \pm 2.8$ & & & & \\
\hline \multirow[t]{3}{*}{8} & I & $13 \pm 2.5$ & $10 \pm 1.2$ & $23 \pm 1.5$ & $34 \pm 2.8$ & & & & \\
\hline & II & $73 \pm 1.4$ & $71 \pm 2.3$ & $65 \pm 4.2$ & $47 \pm 3.8$ & & & & \\
\hline & III & $5 \pm 0.8$ & $3 \pm 0.6$ & & & & & & \\
\hline \multirow[t]{3}{*}{9} & I & $3 \pm 0.4$ & $5 \pm 0.5$ & $11 \pm 1.5$ & $41 \pm 2.8$ & & & & \\
\hline & II & $21 \pm 1.4$ & $22 \pm 1.3$ & $42 \pm 1.2$ & $44 \pm 2.8$ & & & & \\
\hline & III & $65 \pm 4.6$ & $61 \pm 5.6$ & $31 \pm 2.4$ & & & & & \\
\hline \multirow[t]{4}{*}{10} & I & $3 \pm 0.4$ & $3 \pm 0.5$ & $9 \pm 1.5$ & $21 \pm 2.8$ & & & & \\
\hline & II & $3 \pm 1.4$ & $6 \pm 1.3$ & $7 \pm 1.2$ & $46 \pm 2.8$ & & & & \\
\hline & III & $15 \pm 1.6$ & $10 \pm 0.8$ & $3 \pm 0.6$ & $2 \pm 0.3$ & & & & \\
\hline & IV & $65 \pm 5.6$ & $65 \pm 4.3$ & $52 \pm 6.6$ & & & & & \\
\hline \multirow[t]{4}{*}{11} & I & 0.0 & 0.0 & $9 \pm 1.5$ & $13 \pm 2.8$ & & & & \\
\hline & II & $3 \pm 1.4$ & $6 \pm 1.3$ & $3 \pm 1.2$ & $43 \pm 2.8$ & & & & \\
\hline & III & $10 \pm 1.6$ & $5 \pm 0.6$ & $3 \pm 0.6$ & $5 \pm 0.8$ & & & & \\
\hline & IV & $75 \pm 5.6$ & $80 \pm 4.3$ & $62 \pm 6.6$ & & & & & \\
\hline
\end{tabular}

I. - Cleavage; II. - Gastrula; III. - First - stage larva; IV. - Second - stage larva 
Olympus compound microscope with the aid of Multiscan v.4.2 image analysis software.

\section{Infestation of plankton}

Zooplankton was collected from Lake Kortowskie (Poland, Province of Warmia and Mazury) with a plankton net. The samples collected contained copepods (Copepoda) representing the orders Cyclopoida (Cyclops strenuus, Mesocyclops sp., Eucyclops sp., Acanthocyclops sp.) and Calanoida (Eudiaptomus sp., Eurytemora sp.); cladocerans (Cladocera) Daphnia cucullata and Bosmina longirostris; larvae (nauplii of copepods) of crustaceans; and rotifers (Rotifera) Keratella sp., Asplanchna sp., Kellicottia longispina, and Trichocerca cylindrica. A solution containing a large number of the nematode larvae (at least 10 larvae per a potential host) was poured into a container with a plankton sample. After the larvae were supplied, the extent of infes- tation of the zooplankters was checked under the microscope at $1 \mathrm{~h}$ intervals.

\section{Infestation of fishes}

Thirty guppies (Lebistes reticulatus; mean weight and length $0.20 \pm 4.14 \mathrm{~g}$ and $30 \pm 4.52 \mathrm{~mm}$, respectively) from a culture kept in a pet shop in Olsztyn were experimentally infested. The guppies were divided into 3 groups and placed in aerated aquaria. Guppies of group 1 received $1 \mathrm{ml}$ of larval suspension (about 5000 larvae) daily for 3 days; group 2 guppies were offered $1 \mathrm{ml}$ copepods infested with the $C$. rudolphii larvae the day before, and group 3 served as the control. All the groups were fed a standard Supervit feed (Tropical). The fish were autopsied after 2 weeks: all the organs were examined under the stereomicroscope, placed in a digestive fluid ( $2 \%$ pepsin brought to $\mathrm{pH} 2.0$ with $6 \mathrm{~N} \mathrm{HCl}$ ), and incubated for $24 \mathrm{~h}$ at $37^{\circ} \mathrm{C}$ (Jackson et al., 1981).

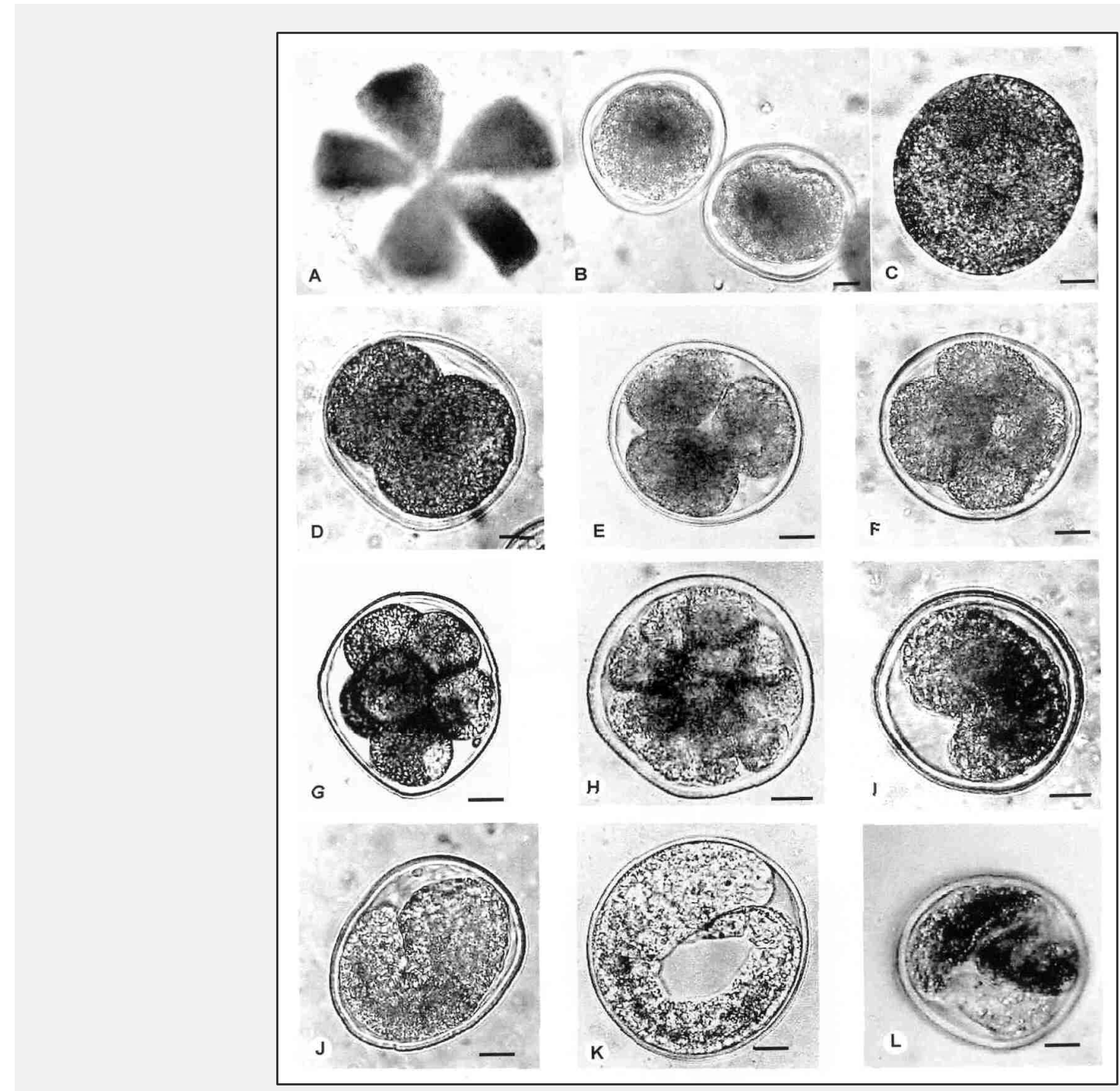

Fig. 1. Contracaecum rudolphii egg development stages. A - oocytes (x 400); B - fertilized egg; C - unfertilized egg; D - egg in 2-blastomers stage; E - 3-blastomers stage; F - 4- blastomers stage; G - 8 blastomers stage; H - morulae; I, - early gastrula; J - gastrula; K - late gastrula „tadpole"; L - first stage larvae molt to the second larval stage. Scale bars $=10 \mu \mathrm{m}$ 


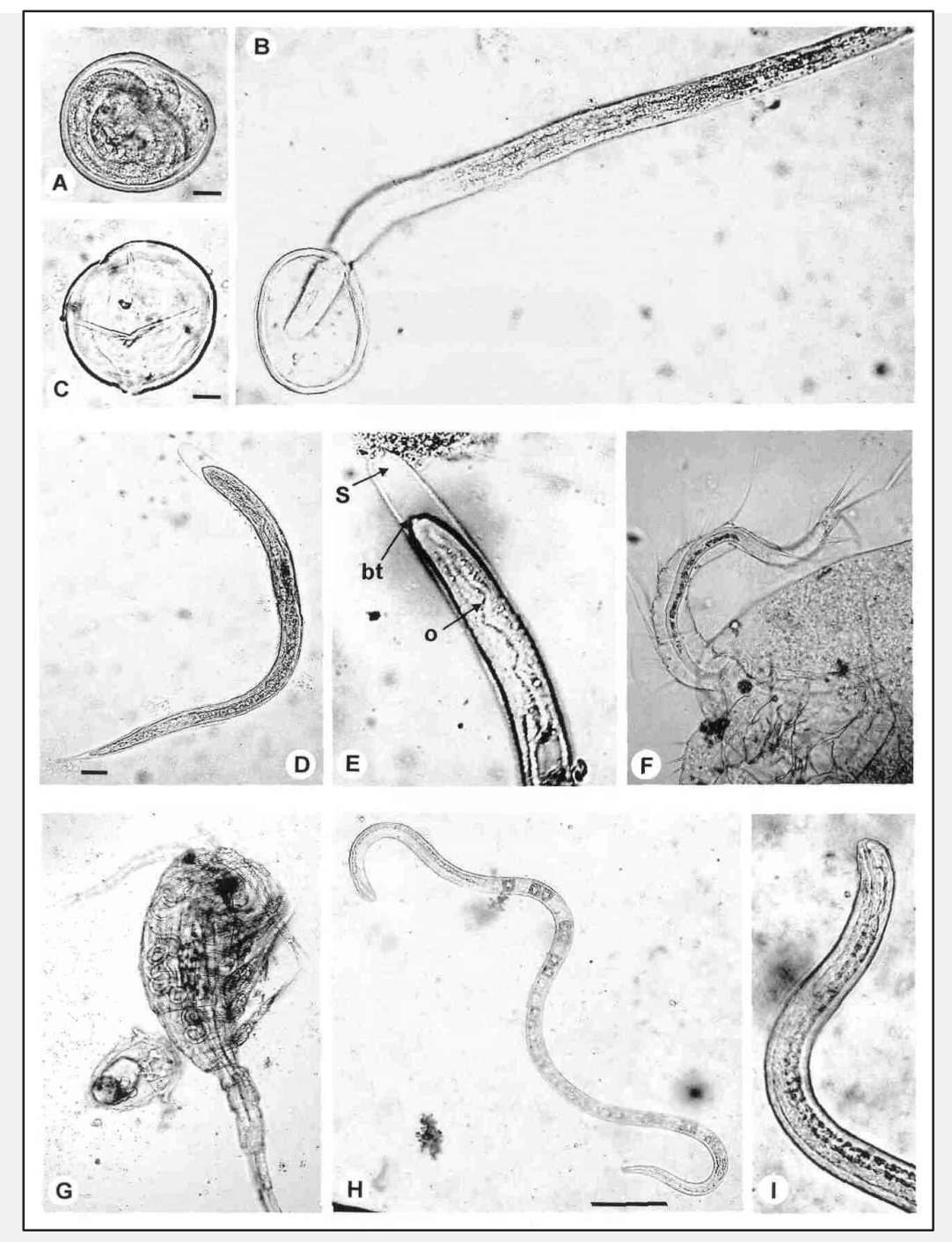

Fig. 2. Stages in the life cycle of C. rudoplphii. A - second stage larvae; B- second stage larvae in process of hatching (x400); $\mathrm{C}-\mathrm{Empty}$ egg shell after hatching; D - newly hatched larva; E - anterior end of newly hatched larva enclosed in the sheath from the second stage larvae (s), note the oesophagus (o) and borning tooth (bt) (x400); F, G - Cyclops sp. with second-stage larvae; $\mathrm{H}-$ larva removed from experimentally infected guppy $($ scale bar $=100 \mu \mathrm{m})$; I - anterior end of the larva from guppy (x 400). A,C, D - scale bars $=10 \mu \mathrm{m}$.

\section{Results}

The female reproductive system of $C$. rudolphii consists of paired, telogenic ovaries and oviducts converging to form a single uterus. Oocytes are fan-shaped and are radially arranged around the nutritive core, connected to it by cytoplasmic bridges (Fig. 1A). The fertilised eggs isolated from the uterus are sub-spherical, their diameter ranging within $51-54 \mu \mathrm{m}(\mathrm{n}=10)$; the eggs are surrounded by a double, transparent membrane (mean thickness $3.1 \pm 0.38 \mu \mathrm{m}$ ). The external membrane is smooth and does not adhere to that of other eggs (Fig. 1B). The membrane was invisible in non-fertilised eggs (Fig. 1C); such eggs disintegrated after a few days. Cleavage was holoblastic and asynchronous. On the day the culture was started, most eggs showed no sign of development; some of them only (about $2 \%$ ) were at the two-blastomer stages (Fig. 1D). Data on
C. rudolphii egg development in various culture media and temperatures are summarised in Table 1. The cultures kept at $23^{\circ} \mathrm{C}$ in tap water, physiological salt solution, and $3 \%$ $\mathrm{NaCl}$ showed most eggs to be at the cleavage stage on the second day (Fig. 1D - H). On the third day, most eggs showed gastrulation (Fig. 1I - K). On the fourth day, $70 \%$ of the eggs contained weakly motile stage 1 larvae (Fig. 1L) which moulted and left their cuticle inside the egg. Stage 2 larvae began to moult when still in the egg (Fig. 2A) and hatched as stage 3, surrounded by a loose-fitting cuticle of stage 2 (Fig. 2 D, E).

The larvae began to hatch 6 days after the culture had been established (Fig. 2B). The egg membrane thickness during cleavage and gastrulation was similar and averaged $2.82 \pm$ $0.76 \mu \mathrm{m}(\mathrm{n}=10)$, while the mean membrane thickness of 
those eggs containing stage 1 and 2 larvae was $2.03 \pm 0.19$ $\mu \mathrm{m}(\mathrm{n}=10)$. About $10 \%$ of the eggs in all the cultures were not fertilised. The eggs kept at $15^{\circ} \mathrm{C}$ were developing at a much slower rate, the individual developmental stages appearing with a time lag of 5 days. The eggs kept at $4^{\circ} \mathrm{C}$ failed to develop. When transferred to $23^{\circ} \mathrm{C}$ after 2 weeks, they resumed development which proceeded similarly to that in the eggs kept at $23^{\circ} \mathrm{C}$ immediately after isolation from the females. About $60 \%$ of the eggs developed to the larval stage.

Regardless of temperature, the eggs placed in $1 \%$ formalin showed numerous deformations; as few as $5 \%$ of those eggs developed to produce larvae.

Those eggs kept for 2 months at $-17^{\circ} \mathrm{C}$ and transferred to $23^{\circ} \mathrm{C}$ failed to develop in any of the samples.

The newly hatched larvae measured, on the average, $250 \pm$ $22 \mu \mathrm{m}(\mathrm{n}=10)$ in length. The larval body was slightly narrowed in the cephalic part (average width $9.5 \mu \mathrm{m}$ ), wider in the mid-part (average width $12.21 \mu \mathrm{m}$ ), and gently narrowing towards the posterior end (average width 8.34 $\mu \mathrm{m}$ ) (Fig. 2D). Most often, the larvae moved out of the egg membranes head first, but sometimes the caudal part emerged first (Fig. 2B). The newly hatched larvae were very active, and surrounded by a loose-fitting cuticular sheath. They were frequently attached, by their cephalic end, to empty egg membranes or to the bottom of the dish. The cephalic end carried a well-developed larval tooth (Fig. 2E). The larvae kept in the physiological salt solution, $3 \% \mathrm{NaCl}$, and tap water at $23^{\circ} \mathrm{C}$ were very active for 2 weeks. At the end of that period, their mean length was $285 \pm 33 \mu \mathrm{m}$. When kept at identical solutions at $5^{\circ} \mathrm{C}$, the larvae were very active for 30 days.

\section{Zooplankton infestation}

One hour after the larvae were supplied to the zooplankton-containing vessel, about $40 \%$ of the cyclopoids ( $\mathrm{Cyc}$ lops strenuus, Mesocyclops sp., Eucyclops sp., Acanthocyclops sp.) were observed to have become infested. No larvae were found in calanoid copepods (Eudiaptomus sp., Eurytemora sp.). The number of infested cyclopoids did not increase with time. For the first 2 hours, all the larvae were located in the cyclopoid intestine. After 3 hours, the larvae were visible in various parts of the cyclopoid body, even far away from the intestine, for instance in the antennae (Fig. 2 F). The cyclopoids infested contained $1-$ 7 larvae each and were more active than the nematode-free individuals. The larvae isolated from the cyclopoids 2 days after infestation were as long as the free-living larvae (265 $\pm 24 \mu \mathrm{m})$. No larvae were present in other crustaceans ( $D$. cucullata, B. longirostris) or rotifers.

\section{Fish infestation}

The fish were autopsied 14 days after they had been offered the parasite larvae (group 1) or infested cyclopoids (group 2). The infestation rate was identical in both groups: a single larva each was found in the body cavity of 2 fish from group 1 and in 2 individuals of group 2. The larvae were not encapsulated; they measured 1123 - 1230 $\mu \mathrm{m}$ in length and $18 \mu \mathrm{m}$ in width (Fig. $2 \mathrm{H}$ ). No larvae were encountered in other parts of the fish body. No larvae were found in the control fish, either.

\section{Discussion}

This study on embryonic development and potential intermediate hosts of $C$. rudolphii demonstrates that the parasite is capable of completing its life cycle in north-eastern Polish lakes. The summer water temperature of about $20^{\circ} \mathrm{C}$ and the availability of intermediate hosts ensure the parasite's persistence in the environment, which in turn may be the underlying cause of the very high prevalence of infestation among the cormorants in Poland (Kanarek et al., 2002). The data on embryonic development of the nematode, obtained in this experiment, are mostly in agreement with the results reported by Huizinga (1966) and Mosgovoy et al. (1968). The eggs of C. rudolphii, as with the eggs of other nematodes of the family Anisakidae, are classified as thin-shelled (Huizinga, 1966; Køie \& Fagerholm, 1995; Højgaard, 1998; Adroher et al., 2004). As the outer membrane of a C. rudolphii egg is smooth, the eggs squeezed out from the uterus are not glued to one another, which most probably enhances dispersal of the parasite in the aquatic environment. The lack of chitinous membrane in the eggs renders them sensitive to various physical and chemical factors. As shown by the experiment described, keeping the eggs for 2 months at $-17^{\circ} \mathrm{C}$ terminates embryonic development irreversibly. Eggs of other ascaridids (geohelminths), provided with a chitinous membrane, may stay in the soil for a long period of time (a few years), and yet the parasites hatched still retain their invasive ability. As shown by Dziekońska-Rynko and Jabłonowski (2004), about $30 \%$ of the eggs of $A$. suum kept for 12 weeks at $20^{\circ} \mathrm{C}$ and transferred to $28^{\circ} \mathrm{C}$ were able to develop. The thin membrane of $C$. rudolphii eggs fails to provide the developing embryos a necessary protection from mechanical damage, either; the eggs are damaged very easily, as observed when they were being squeezed out from the uterus. In addition to their temperature sensitivity, the eggs of $C$. rudolphii are highly sensitive to chemicals such as formalin. In the opinion of Jabłonowski et al. (1981), 1\% formalin is a very good medium for in vitro development of parasite's eggs, as it inhibits fungal growth. Fungi developing in egg cultures reduce the oxygen content in the medium, thus affecting the metabolically aerobic nematode embryos. Jabłonowski et al. (1981) found no adverse effects of formalin solutions of up to $5 \%$ concentration on development of $A$. suum eggs, whereas in this experiment the development was inhibited by a solution as weak as $1 \%$. This result is in agreement with results reported by Huizinga (1966) who found the parasite's eggs to be adversely affected by $2 \%$ formalin, pepsin solution, low temperature, and desiccation. However, Huizinga (1966) failed to provide information on the temperature the eggs had been kept at and the duration of incubation.

In this experiment, as in that described by Huizinga (1966), water salinity did not affect the parasite's embryonic deve- 
lopment. The eggs proceeded to develop in a similar manner regardless of the salinity of the medium. On the other hand, Højgaard (1998) found water salinity to significantly affect development of eggs of $A$. simplex. By following the development of eggs of the parasite in distilled water, the author observed the larvae to die within the egg membranes, the larval mortality rate amounting to $88-98 \%$. The larvae died immediately after hatching in distilled water at $21^{\circ} \mathrm{C}$, while they managed to survive for a few hours in at lower temperatures $\left(5,7^{\circ} \mathrm{C}\right)$. This experiment provided no evidence of salinity effects on motility and survival of the C. rudolphii larvae. Huizinga (1966) reported the larvae of C. rudolphii hatched in sea water and transferred to tap water to swell and die within a few days. In this experiment, the larvae were not transferred from saline to tap water; they stayed all the time in the solutions in which the eggs had been developing. In none of the solutions were the larvae observed to have osmoregulatory problems. Perhaps it was the salinity change that produced osmoregulatory disorders in the experiment reported by Huizinga (1966), while those larvae which stay in the water of a certain salinity all the time evolve mechanisms protecting them from excessive hydration or dehydration. Results of this experiment show the parasite to develop equally well in fresh and in salt water. Further development of the larvae may proceed within a freshwater copepod, as found in this experiment, but also in marine copepods, as reported by Huizinga (1966) and Bartlett (1996). Those larvae kept in physiological salt solution and in tap water at $23^{\circ} \mathrm{C}$ without food were very active for 2 weeks; when kept at a lower temperature, they were active for a month. Like the larvae of other nematodes (A. simplex), the C. rudolphii larvae do not ingest external food during their development and feed on storage materials accumulated in the egg (Sommerville \& Davey, 1976).

The available literature lacks publications on the mechanism of hatching in C. rudolphii larvae. Hatching of the larvae of nematodes such as $A$. suum and $A$. galli the eggs of which have chitinous membranes involves two interdependent processes; one of them is larval stimulation by host-dependent factors $\left(\mathrm{pH}\right.$, temperature, $\left.\mathrm{CO}_{2}\right)$ resulting in the release of a hatching fluid which digests the egg membrane from inside (Jabłonowski et al., 1993). The hatching fluid of those parasites was found to contain a number of enzymes (esterase, aminopeptidase, chitinase, glycosidases) which facilitate hatching by digesting the egg membranes (Young et al., 1999). The available literature lacks publications on the presence of enzymes in the hatching fluid of the Anisakidae. In the opinion of Arthur and Sanborn (1969) and Lee and Atkinson (1976), nematode eggs with thin membranes hatch spontaneously in the external medium, no external stimulation being required for the hatching to begin. At an appropriate larval stage, the vitalline layer becomes permeable to water. Osmotic water penetration increases hydrostatic pressure, which causes the egg membrane to break and facilitates the release of the larva. In this experiment, the egg membrane thickness was observed to change as the embryogenesis progressed. The eggs squeezed out from the uterus and during cleavage are almost spherical. Further on in the development, the membrane becomes thinner and is easily broken by the larva. At that time, the eggs assume different shapes, depending on the orientation of the larva within.

It is debatable whether the eggs of $C$. rudolphii hatch to produce larvae of the second or third stage. In the opinion of Huizinga (1966), Mosgovoy et al. (1968), and Bartlett (1996), the larva moults only once while in the egg; the hatching larvae represent the second larval stage and are surrounded by the sheath of the stage 1 larvae. The present study included observations on moulting; the sheath remaining from the first moult was observed to be left within the egg membranes (Fig 1L). The second moult began just before the larva moved out of the egg membranes; the newly hatched larva was surrounded by the sheath of stage 2. This pattern of moulting deviates somewhat from descriptions of other ascaridid nematodes. The embryonic development of A. suum, Toxocara canis, and Toxascaris leonina, the egg membranes of which are thick, involves two moults, the sheaths from the first and second moult remaining within the egg, and the newly hatching larvae represent the third larval stage (Berry et al., 1981; Bruňanská et al., 1995; Geenen et al., 1999). Results similar to those obtained in this study were reported from observations on in vitro development of Hysterothylacium aduncum (Køie, 1993a; Adroher et al., 2004), Contracaecum osculatum (Køie \& Fagerholm, 1993, 1995) as well as Anisakis simplex and Pseudoterranova desipiens (Køie et al., 1995). According to the authors referred to, the newly hatched larvae represent the third larval stage surrounded by a thin cuticle remaining from the stage 2 larvae. The stage 3 larvae are invasive and end up in their final hosts without an intermediate host (Ascaris spp., Toxocara spp.) or via compulsory intermediate hosts.

In the life cycle of $C$. rudolphii, cyclopoids served as paratenic hosts: the larvae they hosted did not moult and the length of the larvae isolated from them did not differ from that of the free-living larvae. When in the fish body, the larvae grew very quickly, but it is debatable whether they moult there. In the opinion of Huizinga (1966), 18 days after infestation the larvae were still surrounded by the stage 2 cuticle, and some of them retained the cuticular sheath much longer. Similar observations were reported by Bartlett (1996). Mosgovoy et al. (1968) considered the fish to be transporting intermediate hosts only, while dragon-fly larvae served as the compulsory intermediate hosts. Those authors were able to produce infestation in cormorants only when the birds ingested the larvae isolated from the experimentally infested dragon-fly larvae; no nematodes in the cormorant stomachs were found after the birds had been fed the larvae isolated from cyclopoids or fish. Results of the present study, as well as - indirectly - the findings of other authors (Huizinga, 1966; Mosgovoy et al., 1968; Bartlett, 1996) allow to accept the suggestion, put forth by Køie (1993a), that life cycles of most anisakids are similar in that the first two moults occur partially or completely in the eggs. The hatched stage 3 larva may still retain 
the sheaths of the preceding stages. The third moult may occur in the intermediate hosts, but that moult and the fourth one frequently take place in the digestive system of the definitive host.

The study described allows us to conclude that the life cycle of $C$. rudolphii may involve either two or three hosts. Cyclopoids are paratenic hosts and may be redundant in the nematode's development, as no differences in the level of infestation were revealed between the fish infested with the larvae themselves and those fed the infested cyclopoids. The data obtained are not sufficient to claim the fish to be compulsory intermediate hosts, since small larvae do not survive in the bird host. When in the fish body, the larvae grow very quickly: the mean length of the larvae isolated from guppies 14 days after infestation was 1176 $\mu \mathrm{m}$. Huizinga (1966) and Bartlett (1996) reported the mean lengths of $1.4 \mathrm{~mm} 37$ days after infestation and 3.31-3.9 $\mathrm{mm} 152$ days after infestation, respectively. Mosgovoy et al. (1968) found the nematode larvae to grow at the fastest rate when in the dragon-fly larvae, the growth in the fish body being much slower. Publications on $C$. rudolphii larvae in the fish infested under natural conditions are scant (Torres \& Cubillos, 1987; Torres et al., 2000; Kvach, 2005). The larvae isolated by Torres and Cubillos (1987) from Salmo trutta caught in Rio Valdivia (Chile) measured $1.43-2.82 \mathrm{~mm}$. According to Moravec (1994), early stage 3 larvae in fish measured $0.78-0.91 \mathrm{~mm}$, the older stage 3 larvae growing to $15.0-24.0 \mathrm{~mm}$. Køie (1993b, 1999) regarded the small encapsulated stage 3 larvae measuring $1.5-3.5 \mathrm{~mm}$ in length, found in the North Atlantic fish, to be those of $C$. rudolphii. Most probably, the larvae dwelling in fish have been overlooked on fish examination because of their small size. The high prevalence and intensity of cormorant infestation may be taken as a suggestion that the parasite is fairly common in the ichthyofauna.

Perhaps the extent of the parasite infestation in fish could be assessed by applying the methods described by Jackson et al. (1981) which involve digestion and sedimentation. The parasite's pathogenicity in fish, birds, and mammals is still a matter of debate. However, as pointed by numerous authors (Dick et al., 1987; Abollo et al., 2001; Yang et al., 2000; Yang et al., 2001), the parasite may cause death of birds and cause economic losses in fish cultures.

\section{Acknowledgement}

This work was supported by the Ministry of Education and Science grant No. 0420/PO4/2005/28

\section{References}

Abollo, E., Gestal, C., Pascual, S. (2001): Anisakid infection in the European shag Phalacrocorax aristotelis aristotelis. J. Helminthol., 75: $209-214$

Adroher, F. J., Malagón, D., Valero, A., Benitez, R. (2004): In vitro development of the fish parasite Hysterothylacium aduncum from the third larval stage recovered from a host to the third larval stage hatched from the egg.
Dis. Aquat. Org., 58: $41-45$

ARTHUR, E. J., SANBORN, R. C. (1969): Osmotic and ionic regulation in Nematodes. In FlorkIN, M., SchEER, B. T., KIDDER, G. W. (Eds.): Chemical Zoology. Acad. Press, New York and London, 3: 429 - 464

BARTLETT, C. M. (1996): Morphogenesis of Contracaecum rudolphii (Nematoda: Ascaridoidea), a parasite of fish-eating birds, in its copepod precursor and fish intermediate hosts. Parasite, 4: $367-376$

BERRY, G. N., CANNON, L. R. G. (1981): The life history of Sulcascaris sulcata (Nematoda: Ascaridoidiae), a parasite of marine mollusks and turtles. Int. J. Parasitol 11: 43 - 54 BRUŇAnskÁ, M., DubinskÝ, P., REITTEROVÁ, K. (1995): Toxocara canis; Ultrastructural aspects of larval molting in the maturing eggs. Int. J. Parasitol., 25: $683-690$

Dick, T. A., PAPST, M. H., PAul, H. C. (1987): Rainbow Trout (Salmo gairdneri) stocking and Contracaecum spp. J. Wildl. Dis., 23: $242-247$

DZIEKOŃSKA-RYNKO, J., JABŁONOWSKI, Z. (2004): The effect of low temperature on the development of eggs of $\mathrm{As}$ caris suum Goeze, 1782. Wiad. Parazytol., 50: 509- 512

DZIKA, E. (2003): Metazoan parasites of roach Rutilus rutilus (L.) in the lakes of Mazury Destrict as a quality indicator of aquatic environment. Dissertations and monographs. UWM Olsztyn

Geenen, P. L., Bresciani, J., Boes, J, Pedersen, A., Eriksen L, Fagerholm, H.-P., NAnsen, P. (1999): The morphogenesis of Ascaris suum to the infective third-stage larvae within the egg. J. Parasitol., 85: 616-622

HøJGAARD, D. P. (1998): Impact of temperature, salinity and light on hatching of eggs of Anisakis simplex (Nematoda, Anisakidae), isolated by a new method, and some remarks on survival of larvae. Sarsia, 83: $21-28$ Huizinga, H. W. (1966): Studies on the life cycle and development of Contracaecum spiculigerum (Rudolphi, 1809) (Ascaroidea: Heterocheilidae) from marine piscivorous birds. J. Elisha Mitchell Sci. Soc., 82: $181-195$

HuizingA, H. W. (1971): Contracaeciasis in pelicanform bird. J. Wildl. Dis., 7: $198-204$

JABŁONOWSKI, Z., ŁUKASZEWICZ-BABECKA, J., PIECHOCKI, D. (1993): The processes connected with hatching of larvae from eggs of parasitic nematodes. Wiad. Parazytol., 39: $3-12$

JABŁONOWSKI, Z., ŻEBROWSKA, T., DZIEKOŃSKA, J. (1981): The effect of glycerol, parafin, rape oil and aqueous solutions on the development of eggs of Ascaris suum Goeze, 1782. Wiad. Parazytol., 27: $17-23$

JaCkson, G. J., Bier, J. W., PAYne, W. L., McClure, F. D. (1981): Recovery of parasitic nematodes from fish by digestion or elution. Appl. Environ. Microbiol., 41: $912-$ 914

KanareK, G., Rolbiecki, L., Sitko, J., Baruš, V., RoKICKI, J. (2002): The occurrence of Contracaecum rudolphii Hartwig, 1964 in cormorant (Phalacrocorax carbo sinensis) in norhern Poland. 5. slovenské a české parazitologické dni. Program a zbornik abstraktov. s.22

KøIE, M. (1999): Metazoan parasites of flounder Platichthys flesus (L) along a transect from the southwestern to 
the northeastern Baltic Sea. J. Marine Sci., 56: 157 - 163 KøIE, M. (1993a): Aspect of the life and morphology of Hysterothylacium aduncum (Rudolphi, 1802) (Nematoda, Ascaridoidea, Anisakidae). Can. J. Zool., 71: 1289-1296 KøIE, M. (1993b): Nematode parasites in teleosts from 0 to $1540 \mathrm{~m}$ depth off the Faroe Islands (the north Atlantic). Ophelia, 38: $217-243$

KøIE, M., Berland, B., Burt, M. D. B. (1995): Development to third stage larvae occurs in the eggs of Anisakis simplex and Pseudoterranova desipiens (Nematoda, Ascaroideae, Anisakidae). Can. J. Fish. Aquat. Sci., 52: $134-$ 139

KøIE, M., Fagerholm, H. P. (1993): Third - stage larvae emerge from eggs of Contracaecum osculatum (Nematoda, Anisakidae). J. Parasitol., 79: $777-780$

KøIE, M., Fagerholm, H. P. (1995): The life cycle of Contracaecum osculatum (Rudolphi, 1802) sensu stricto (Nematoda, Ascaridoidea, Anisakidae) in view of experimental infections. Parasitol. Res., 81: 481 - 489

Kuiken, T., Leighton, F. A., Wobeser, G., Wagner, B. (1999): Causes of morbidity and mortality and their effect on reproductive success in double-crested cormorants from Saskatchewan. J. Wildl. Dis., 35: 332 - 346

KVACH, Y. (2005): A comparative analysis of helminth faunas and infection parameters of ten species of gobid fishes (Actinopterygii: Gobiidae) from the north - western Black Sea. Acta Ichthyol. Pisc., 35: $103-110$

LeE, H., AtKinson, H. J. (1976): Physiology of nematodes. MacMillan Press, N. Y.: $116-129$.

Martyniak, A., Terlecki, J., Boroń, S., Hliwa, P., SzAMAŃSKA, U., GABRYŚ, B., RoMANIEWICZ, A. (1997): Diet composition of cormorants Phalacrocorax carbo sinensis from pellets collected at Katy Rybackie colony, northern Poland. Ric. Biol. Selvaggina, Suppl., 26: 505 - 510

Martyniak, A., Wziatek, B., Szymanska, U., Hliwa, P., TERLECKI, J. (2003): Diet composition of Great Cormorants Phalacrocorax carbo sinensis at Katy Rybackie, NE Poland, as assessed by pellets and regurgitated prey. Vogelwelt, suppl., 124: $217-225$

MORAVEC, F. (1994): Parasitic nematodes of freshwater fishes of Europe. Academia, Prague

Mosgovoy, A. A., Shakhmatova, W. I., Semenova, M. K. (1968): Life cycle of Contracaecum spiculigerum (Ascaridata: Anisakidae), a parasite of domestic and game birds. Trudy Gelmintol. Lab. 19: 129 - 136

NOTTENKÄMPER, D., KORBEL, R., KÖSTERS, J. (1999): The infection of great cormorants (Phalacrocorax carbo sinensis L. 1758) with Contracaecum rudolphii (Nemato- da: Ascaridoidea) in the district of Upper Bavaria (Germany) and the canton St. Gallen (Switzerland). Tierärztl. Prax. Kleintiere, 4: 27

Olsen, O. (1962): Animal parasites: Their biology and life cycles. Burges Pub. Co., Minneapolis, Minn.

ROLBIECKI, L. (2003): Diversity of the parasite fauna of cyprinid (Cyprinidae) and percid (Percidae) fishes in the Vistula Lagoon, Poland. Wiad Parazytol., 49: 125 - 164

Sanmartin, M. L., Cordeiro, J. A., Alvarez, M. F., LeIRO, J. (2005): Helminth fauna of the yellow-legged gull Larus cachinnans in Galicia, north-west Spain. J. Helminthol., 79: $361-71$

Sommerville, R. I., DAVEY, K. G. (1976): Stimuli for cuticle formation and ecdysis in vitro of the infective larva of Anisakis sp. (Nematoda: Ascaridoidea). Int. J. Parasitol., 6: $433-439$

Thomas, L. J. (1937a): On the life cycle of Contracaecum spiculigerum (Rud). J. Parasitol., 23: 429 - 431

THOMAS, L. J. (1937b): Futher studies on the life cycle of Contracaecum spiculigerum. J. Parasitol., 23: 572

Torres, P., Cubillos, V. (1987): Infection with larvae of Contracaecum (Nematoda, Anisakidae) in Salmonids acclimatized in Chile. J. Vet. Med. B., 34: 177 - 182

Torres, P., Ortega, J., Schlatter, R. (2005): Nematode parasites of the digestive tract in Neotropic cormorant chicks (Phalacrocorax brasilianus) from the River Cruces Ramsar site in southern Chile. Parasitol. Res., Online First (http://parasitology.informatik.uni-wuerzburg.de/login/n/h/ j_005-1372-0.html.linked)

Torres, P., Valdiviesa, J., Schlatter, R., MontefusCO, A., Revenga, J., MARIN, F., LAMilla, J., RAMAllo, G. (2000): Infection by Contracaecum rudolphii (Nematoda: Anisakidae) in the Neotropic cormorant Phalacrocorax brasilianus, and fishes from the estuary of the Valdivia river, Chile. Stud. Neotrop. Fauna \& Environm., 35: 101 108

YAng, T. B., LiaO, X. H., Zeng, B. P. (2000): Population ecology of Contracaecum rudolphii in the host Gymnocypris przewalski przewalski in the Qinghai Lake. Acta Hydrobiol. Sin., 24: $213-218$

YANG, T. B, MiaO, S. Y., LiAO X.H., WANG, Z.J. (2001): Studies on the dynamic mechanism of cavity helminthes in Gymnocypris przewalski przewalski in the Qinghai Lake Acta Hydrobiol. Sin., 25: 268 - 273

YounG, A. R., Mancuso, N., Bowles, V. M. (1999): Biochemical aspects of egg hatch in endo- and ectoparasites: potential for rational drug design. Int. J. Parasitol., 29: 861 $-867$ 